\title{
RECEN SIONS
}

\section{ASALS, Jaume}

El pou dela paraula. U na història de la saviesa grega

Barcelona, 1996, 100 p.: Edicions 62, 1997

Al principi del seu llibre, Jaume $C$ asals presenta l'experiència d'apropament als textos de l'antiguitat grega i n'accentua la distància, la diferència i l'exotisme d'un pensament i d'una concepció del món que constitueixen el nostre origen. Els hereus de la saviesa grega, els filòsofs acadèmics de l'actual itat (professors de fil osofía), només poden albirar «en mons insospitats i en percepcions secretes [... ] detalls de l'experiència i del pensament antics» ( $p$. 1314). Aquest llibre, però, busca retallar aquestes diferències mitjançant la lectura d'alguns fragments de textos grecs i d'aquells filòsofs preferits per l'autor on encara ressona amb força la paraula grega en tota la seva originalitat.

Les quatre seccions d'aquest Ilibre s'articulen sempre en un diàleg entre un text de l'antiguitat (H omer, Aristòtil i Zenó, Parmènides, Pirró) i els comentaris 0 interpretacions que d'aquest text en feren autors més propers a nosal tres ( $N$ ietzsche, Bergson, $\mathrm{H}$ eidegger, M ontaigne). La línia que $C$ asals traça entre aquestes dues èpoques constitueix la «tesi» que fa que aquest llibre sigui una història de la saviesa antiga i no una altra. Ésa dir, Casals pren partit per l'estil de $\mathrm{N}$ ietzsche 0 de Rohde enfront del de W ilamowitz i Jaeger, però darrere d'aquesta presa de partit no hi ha una decisió arbitrària, ni tampoc una decisió exclusivament científica, sinó quelcom que ja ens va sorprendre en el seu llibre anterior (L'experiment d'Aristòtil. Literatura d'una incursió en la metafísica, Edicions 62, Barcelona), on s'expressava, de mane ra més punyent encara, el desgrat, l'avorriment i el fàstic enfront deles formes més comunes que ha adoptat la filosofia actual (quelcom que podria caure més 0 menys sota l'epígraf de «filosofia analítica»); una filosofia que ha provat d'eliminar l'el ement que més enriqueix el present llibre: la paradoxa. I és que precisament la paradoxa, en instal.lar-se al bell mig de l'argumentació, al nucli de les explicacions, en constituir allò essencial de la paraula, recupera (i aquesta és la tesi de ( asals) un moment en què la paraula filosòfica encara campava per quelcom anterior i diferent al principi que, situantse en el centre de comandament del pensament, impedia que es pogués dir al hora que una cosa és i no és.

Agosaradament, en aquest llibre es repensa el moment fundacional on la filosofia, aliena a un discurs ocupat a delimitar les condicions de possibilitat de si mateix, encara no s'ha erigit en contraposició res- 
pecte de l'opinió, com farà el discurs platònic sobre la doxa.

Així, aquest és un Ilibre d'història de la filosofia que va més enllà de l'exposició de clixés pròpia d'un model encara present a la nostra acadèmia. En un gest semblat al de H eidegger, però amb originalitat pròpia, l'autor repensa els orígens del que avui anomenem filosofia a partir, per exemple (v. cap. 3 «E) pensament original»), dels textos de Parmènides, els quals prova de rellegir deslliurant-los de la dogmatizació i l'enclaustrament en esquemes fixos que patiren a mans de Plató (sense caure, però, tampoc en la seva recorrent i heideggeriana demonització com a iniciador de la història d'un error). D 'aquesta lectura acurada, sorgeix una nova imatge de la saviesa arcaica que no vol «donar comptes de cap esdeveniment escolar fora de l'esdeveniment [...] pròpiament "filosòfic", que s'interessa «pel que, dels grecs - fins i tot de grecs molt tardans com $\mathrm{M}$ ontaigne, $\mathrm{N}$ ietzsche, Bergson 0 $\mathrm{H}$ eidegger - , ens pot convidar de veritat a tornar a parlar» (p. 10). A I'hora d'apropar-se i d'apropiar-se d'aquest pensament de l'origen, aquest llibre combina, d'una banda, una anàlisi filològica acurada que fa referències a diverses perspectives $i$ tradicions interpretatives amb, d'altra banda, una voluntat de fer filosofia amb majúscules, si és que aquest és el nom que ha de rebre la tasca de pensar. C asals resol aquesta doble tasca amb un estil propi en el qual el llenguatge veu sobtadament enriquit el seu àmbit d'acció fins a incloure amb tota natural itat allò que des d'A ristòtil i Plató ens ha impedit l'accés al veritable sentit de la saviesa arcaica: les paradoxes i les contradiccions. És aquest estil el que justifica allò que ja se'ns avança al pròleg («Els quatre escenaris grecs històrics que inspiren aquest Ilibre assenyalen tots, cadascun a la seva manera, la paraula alhora respectuosa i a ultrança, la paraula que no eixorda i que tanmateix no calla, la poesia», p. 10) i que en cada capítol es demostrarà amb escreix ( «l no és simplement poesia, només poesia, la paraula dels antics grecs?», p. 74). $C$ asals és conseqüent, com ho demostra el seu estil i la seva paraula, amb dues afirmacions: a) en la saviesa arcaica hi ha quelcom que constitueix I'origen del que s'ha petrificat cofoiament amb el nom de filosofia i b) aquest origen és poètic, per tant forma part d'una disciplina que no és la filosofia, sinó de quelcom abstracte que, pel seu caire més suggerent que argumentatiu, és més a prop d'un concepte de poesia (o d'art) en el sentit més ampli d'a quest terme. Sembla evident que, si volguéssim extreure d'això una afirmació normativa, es produiria una liquidació dels límits entre les dues formes d'expressió i quedaria anul.lada així la divisió que, de fet, els atorga sentit. La possibilitat, doncs, que ens resta és la que sembla practicar l'autor: sense abandonar un interès decididament filosòfic, ampliar les possibilitats expressives de la filosofia, de manera que I'argumentació recolzi en mitjans inherents a l'essència de la paraula («l'ombra de la paraula», la metàfora, el símil, el joc... ), mitjans que semblen arribar més enllà (i fer més agradable) del fred discurs dela raó. 


\section{DESCARTES, René \\ D iscurs del mètode}

Traducció i edició a cura de Pere Lluís Font, Edicions 62, «Textos filosòfics», Barcelona, 1996

Amb el número 74 de la col·lecció «T extos filosòfics» (a la meitat, doncs, dels cent cinquanta volums originàriament previstos, com si en volgués certificar la maduresa) arriba la versió catalana d'una deles obres més indiscutiblement clàssiques de la història de la filosofia, el D iscurs del mètode de D escartes, en una edició acurada i una traducció esplèndida. Edició, val a dir-ho, del Discurs del mètode solament, sense els A ssaigs científics als quals, en la primera edició de l'obra, aquell feia formalment de pròleg (i l'índex dels quals és afegit aquí en forma d'apèndix), defugint el parer dels que jutgen que una publicació així adultera el sentit de les intencions de $D$ escartes, que hauria pensat el D iscursi els Assaigs com un tot inseparable. La rotunditat dels arguments amb què P. LI. defensa la legitimitat de la seva decisió duen a pensar que una denúncia com l'esmentada acaba essent, ben mirat, presonera de les aparences (en aquest cas, els avatars editorials de l'obra cartesiana), perquè hi ha dades suficients per sostenir que D escartes considerava el D iscurs com un text perfectament autònom.

Tot i que la intenció principal amb què aquesta recensió ha estat encarregada a qui la signa és la de judicar la traducció del text cartesià, no em sé estar de fer abans un parell de remarques sobre l'edició pròpiament dita, introducció i notes, que suposen en el volum una aportació més important del que és ordinari en la col·lecció que l'acull. Perquè, efectivament, introducció i notes subministren a gavadals matèria de reflexió i pistes per fer fructífera la lectura: des de la presentació biogràfica inicial i el crit d'alerta davant de la tendència a tenir en compte únicament un aspecte de D escartes («fentne la personificació unilateral de l'esperit de geometria, sense esperit de finesa») fins a les dades de la cronologia (que no només forneixen informació general al lector comú, sinó que diuen la seva també en al guns dels punts més debatuts pels especialistes); des de la vocació pedagògica de les notes, que tenen com a objectiu assegurar al lector la comprensió del pensament de $D$ escartes, fins a les que suposen una presa de partit en qüestions cabdals per a la interpretació del cartesianisme ( $p$. ex., n. 157 i 250); des de les observacions de caràcter senzillament informatiu (doctrinal o històric) fins a les remarques que pretenen il-luminar zones que habitualment resten en la foscor (p. ex., n. 97), lluïssors insòlites que fan bona aquella definició borgiana dels clàssics: «és clàssic aquell Ilibre que una nació o un grup de nacions o el tempshan decidit dellegir com si en les seves pàgines tot fos deliberat, fatal, profund com el cosmosi capaç d'interpretacions sense fi» ( ¿Sobrelos lásicos》, 0 tras inquisiciones; a: O brascompletas, 3 v., Emecé, Barcelona, 1989; vol. 2, 151).

La introducció dedica bona part de les seves pàgines a dues qüestions disputades entre els intèrprets (més una tercera, resolta en forma de nota, relativa al grau de continuïtat o discontinuïtat entre la metafísica del D iscurs i la de les M editacions metafísiques, i que P. LI. considera substancialment una, en oposició al parer d'alguns il.lustres especialistes - particularment, Alquié): es tracta de l'assumpte de la historicitat del relat del Discursi del de la seva unitat de composició. Pel que fa a aquesta segona qüestió, P. LI. resumeix amb claredat els elements que configuren l'estat de la qüestió, en una operació que pressuposa una anàlisi minuciosa i una sàvia ponderació de les dades en joc, internes i externes; és just de destacar l'apor- 
tació original quefaP. LI. aquí, en el context de la discussió sobre l'existència o no d'una $\mathrm{H}$ istoire de mon esprit (esmentada en una lletra de Balzac a D escartes, de 1628) suposadament emprada en la primera part del D iscurs: la H istòria mencionada per Balzac podria ser I'Studium bonae mentis, text perdut, probablement escrit el 1622, i que, si s'ha de jutjar per les notícies que en dóna Baillet, presenta similituds sorprenents (i sorprenentment negligides per generacions de comentaristes) amb els passatges paral $\cdot$ lels del $D$ iscurs. $Q$ uant a la qüestió de la fidelitat històrica de l'autobiografia exposada en el D iscurs, P. LI. la resol amb singular elegància, explotant amb encert l'al·lusió cartesiana al caràcter de faula de la història que ens descriu. L'autobiografia del $D$ iscurs seria, en efecte, una història ideal (amb bastants punts de contacte, d'altra banda, amb la història real de R ené D escartes), i I'ensenyament que ofereix serial'exposició de la gènesi ideal del cartesianisme, anàlogament a com la cinquena part del D iscurs ens mostra la gènesi ideal del món i de l'home, no pas com a expedient enginyós de caràcter pragmàtic (la condemnació de G alileu és ben recent), sinó com a «forma d'exposició típicament cartesiana» (p. 135, n. 170). Si molt no m'erro, la lectura de l'article 204 de la quarta part dels Principis de la filosofia refermaria encara la lectura de P. LI.

En conjunt, la introducció i les notes d'aquesta edició fan del D iscurs una magnífica presentació global del cartesianisme; de fet, el D iscursmateix ja ho és, però tot passa com si P. LI. aprofités I'avinentesa per completar-la i, en quatre ratlles, acabar de perfilar la posició de D escartes en aquelles qüestions que hi són tot just esbossades: la teologia (n. 30), la política (n. 56, $96)$, la moral (n. 92, 111), la medicina (n. 260), I'epistemologia (n. 264 s.), i d'altres. Es tendeix així a dibuixar l'arquitectura completa del sistema cartesià, en el que acaba essent un assaig virtual, i que un desitjaria que esdevingués actual.
Q uant a la traducció pròpiament dita, em fal'efecte que és modèlica, conjumina amb encert el respecte i la fidelitat envers I'original i la sensibilitat lingüística. Ja les primeres notes deixen constància de l'escrupolositat amb què la traducció ha estat realitzada, de l'esforç fet per mantenir els matisos de l'original, de la cura per evitar afegir ambigüitats o ressonàncies gratuïtes (cf. p. ex. n. 61). El grau de precisió que cal agrair que P. LI. s'hagi volgut imposar fa que la traducció sigui, de vegades, valenta: així, i per posar-ne un exemple conegut (p. 90), es parla amb exactitud d'un D escartes «tancat en una estufa» («enfer mé dans un poêle»), sense subterfugis com ara «vora una estufa» o similars, a què la pusil.lanimitat obliga en al tres traductors; evitar que l'audàcia esdevingui temeritat força, és clar, P. LI. a la nota (també els editors francesos acostumen a posar-la-hi), en una gentilesa que li hauria agraït aquell lector eixel ebrat que s'imaginava el pobre D escartes arraulit dins I'aparell...

Punt i a part mereix l'anàlisi de la manera com ha estat traduïda la locució més cèlebre del $D$ iscurs del mètode, la famosa expressió «je pense, donc jesuis» (P. LI., p. 119: «penso, ergo existeixo»). I aquí he de dir que la solució final adoptada per $P$. LI., en ella mateixa impecable, no m'aca ba de convèncer. I, al menys parcialment, per la mateixa raó adduïda al seu favor: «que sigui literal i que al hora resulti tan natural i lapidària com la de l'original francès» (n. 133). El donc francès és la manera natural d'introduir la conclusió d'un sil.logisme; és ben sabut que D escartes va protestar sovint davant de les interpretacions que feien del cogito un raonament, en comptes d'una intuïció singular: però justament això mostra que, la locució com a tal, convida a la dita interpretació. Cal, doncs, com explica perfectament P. LI., traduir conservant el caràcter consecutiu de la conjunció francesa. El problema ve amb la tria. L'equivalent català natural seria «doncs», que compleix també la funció requerida d'introduir la 
conclusió d'un raonament. Si el que es vol és no afavorir una mala interpretació fruit del vici consistent a atorgar al «doncs» un valor causal, la fórmula natural em fa l'efecte que hauria de ser la locució «per tant». L' «ergo» resulta, al meu parer, massa savi; justament, poc natural. Potser n'és un indici la manera vacil ·lant com el tracta la Gran Encidopèdia Catalana (a desgrat de la claredat del Fabra o el Coromines): exclòs de la llista de les conjuncions consecutives (s.v. consecutiu-iva), és tractat (s.v. ergo) com a conjunció i qualificat de «mot llatí» amb el significat de «doncs» 0 «per tant». U na vegada més, la GEC no és aquí gaire modèlica; però potser sí que la seva hesitació és en aquest cas simptomàtica. $D$ 'altra banda, hi ha la qüestió del caràcter lapidari de la fórmula cartesiana: és possible que traduir «penso, per tant existeixo» sigui una mica llarg. Però la locució em sembla retrobar el seu punt si mantenim «sóc» en comptes d' «existeixo», i per què no fer-ho? El sentit cartesià del verb «ésser»és aquí, certament, existencial. Però per què no concedir al català el mateix joc que al francès, que jugarà, quan li convingui (i en D escartes mateix podríem trobar un bon grapat d'exemples), amb els dos termes, être i exister? A més, el matís que, si hem de creure Gilson (L'être et l'essence, V rin, París, 1948), dis tingeix en alguns escolàstics exsistere («ex alio sistere») d'esse no està tan lluny en el temps com per no deixar constància neta de la manera com el seglexvı fa anar els dos mots. D 'al tra banda, l'expressió cartesiana esdevindrà gai rebé proverbial, i la posteritat la farà anar i venir com bellament li plaurà; Iligant-la tan curt com sigui possible, la traducció tindrà més possibilitats de valer en aquests al tres contextos imprevisibles. Penso, per exemple, en aquella picada d'ullet (cartesiana no només en la forma, sinó també en el fons) de Rimbaud: «je me crois en enfer, donc j'y suis» («U ne saison en enfer», a 0 euvres complètes. Correspondance, Laffont, París, 1992, p. 146).
La mateixa recerca de naturalitat em fa néixer un escrúpol davant de la traducció del substantiu êtreper ens (cf. p. ex. p. 125). És veritat que la traducció Ilatina del D iscurs ho avala, així com el fet que, a diferència de l'equival ent francès étant, neologisme de creació relativament recent, el català té «ens» documentat des de Llull. Però no per això deixa de resultar una mica encarcarat, almenys en un text com aquest; jo m'hauria inclinat, senzillament, per «ésser» (diem «éssers vius», «éssers humans»).

Q ue aquestes lleugeres discrepàncies no ens confonguin. Són qüestió de gust més que al tra cosa (i dels gustos estilístics, més potser que de cap altre, no es deu haver de disputar, tot i quela propensió del país a fer-ho sigui prou coneguda). Ens trobem davant d'una traducció que, ultra pel rigor quant a la fidelitat (que ens permet disposar en català d'un D iscurs del mèto de lliure d'errors, cosa que no garantia la traducció clàssica de J. Xirau, que conte nia al guna badada espectacular, com ara aquella que ens feia «mestres [maîtres] i possë dors de la natura»), ha de ser remarcada sobretot pel fet d'haver estat capaç d'oferir al lector un text final magnífic, alhora ric i debon llegir, que fa justícia a I'estranya màgia de l'original, que ens sedueix amb el que en podríem dir, a risc de paradoxa, I'exuberància de la seva senzillesa, model exemplar d'allò que Proust Iloava al segle XVII francès: «una manera simple de dir coses profundes» («À propos du "style" de Flaubert», N ouvelle Revue Française, gener de 1920; a: Essais et artides, Gallimard, París, 1994, p. 282). Es tracta, a més, d'una edició en riquida amb multiplicitat de consideracions i remarques pertinents, fruit d'aquella familiaritat i assiduïtat amb el pensament de l'autor que ha d'estar a la base de tota aproximació que vulgui ser al hora honesta i fecunda, d'acord amb aquell principi historiogràfic que enunciava V. D elbos, i que els que hem tingut el plaer de ser alumnes de P. LI. li hem sentit citar tan 
sovint: defugir «aquells jocs de reflexió que, amb el pretext de descobrir la significació profunda d'una filosofía, comencen per negligir-ne la significació exacta» (La philosophie pratique de Kant, Alcan, París, 1905; reed. PUF, 1969, p. 1). Una edició i traducció modèliques i, en defi-

Franco BarRIo, Jaime Kierkegaard frente al hegelianismo Universidad de Valladolid, 1996

El texto de Jaime Franco Barrio sobre Kierkegaard y su relación con el hegelianismo, tanto en general cuanto en su versión danesa, es, como el autor mismo indica en el prólogo, un estudio de corte histórico. Por ello, el texto propiamente dicho se inicia con un apartado repleto de referencias sumariales a la vida y obra de contemporáneos de Kierkegaard, con quien éste tuvo al gún tipo de relación. $\mathrm{El}$ pensamiento de Kierkegaard es, así, contextual izado históricamente. Pero no problematizado. El autor asume en su mayor parte las tesis de los autores a los que cita abundantemente a lo largo del trabajo, en especial a $\mathrm{N}$ iels Thulstrup y su conocida obra Kierkegaard's relation to $\mathrm{H}$ egel (Princeton 1980, aunque aparecida ya en danés en1967), y aprovecha asimismo vivamente la labor recopilativa y documental de éste. En general, el trabajo de Franco Barrio muestra un gran dominio de la bibliografía secundaria, aunque no siempre goce de la misma transparencia. En este sentido, resulta inexplicable ya en el prólogo la absoluta falta de referencia a la obra de André Clair, Pseudonymie et Paradoxe La pensée dialectique de Ki erkegaard, V rin: París, 1976, en cuya «ntroducción» ( $p$. 11-19) es posible encontrar el mismo esquema de «lecturas» de la obra de Kierkegaard que Franco Barrio reproduce en un resumen, incluida una nota que Clair dedica a un conocido texto de M ar- nitiva, plenes de bon sentit; que potser sí que és la cosa del món més ben repartida; però massa sovint un té la sensació que, el dia del repartiment, més d'un no hi devia ser...

J osep 0 lesti guerite $G$ rimault sobre la melancolía en la obra de K ierkegaard (p. 333, n. 10).

Por lo que respecta al tratamiento de la obra de Kierkegaard, citada de la primera edición danesa, la lectura de F ranco Barrio no es tampoco de corte crítico. El autor no pone cuestiones al texto kierkegaardiano; más bien, elimina el rastro de toda cuestión posible en su lectura antihegel iana. Así, no concede ningún tipo de significación temática al carácter pseudónimo de la obra de K ierkegaard (en distintas ocasiones, Franco Barrio alude a «K ierkegaard (o su pseudónimo de turno)», p. ej. p. 75), que, en cambio, es su principal objeto de análisis, y, con ello, desgraciadamente, no solamente se tergiversan al gunas citas en relación con su contexto (en la primera carta del Juez W ilhelm a su amigo A, en el segundo volumen de 0 bien esto, o bien aquello, Franco Barrio quiere leer «filósofo especulativo» allí donde sólo cabe leer «esteta», y, así, quiere leer «filosofía» donde sólo cabe leer «poesía», actuación estética, por tanto - p. 41 , notas 28 y 29 , p. ej.), sino que se confunden y se mezclan los discursos, tanto su tono cuanto su propósito, y así las categorías. D a la impresión de que la lectura de Franco Barrio del texto kierkegaardiano está falta de un rigor que sólo brota del close rea ding, impedido aquí por convicciones y tesisajenas tanto a la reflexión y al texto de 
Franco Barrio como también al propio texto de Kierkegaard.

La lectura de Franco Barrio resulta, pues, una lectura relativamente indiscriminada y poco matizada, donde el texto y el pensamiento kierkegaardianos no acaban de verse liberados del cliché, en ocasiones caricaturesco, de la mayor parte de lecturas desde los años sesenta hasta hace una década. Se trata de una lectura donde ambos, texto y pensamiento, sufren precisamente del rigorismo al que se oponían y donde, finalmente, es difícil captar la significación de los matices para la reconceptualización filosófica de la existencia a la que tanto esfuerzo dedican. En este sentido, el valor principal de la

SCHLEGEL, Friedrich

El etudio de la poeśá griega

Akal, 1996

En su tesis doctoral sobre el concepto de crítica de arte en el romanticismo alemán W al ter Benjamin dice: «A título de teoría romántica de la crítica de arte se expone a continuación la de F riedrich Schlegel. El derecho a designar esta teoría como la teoría romántica se apoya en su carácter representativo. No se trata de que los primeros románticos estuvieran de acuerdo con ella, ni siquiera que tuvieran noticia al guna al respecto. Friedrich Schlegel resultaba frecuentemente incomprensible incluso para sus amigos. Pero su intuición de la esencia de la crítica de arte es la voz de la escuela a ese propósito. Él hizo de este tema, en tanto que objeto problemático y filosófico, el suyo propio - cuando no el único»1. Y Ernst R. Curtius: «M uchos son los desagravios que debemos a Friedrich Schlegel, pues ningún gran autor de nuestra edad de oro ha sido tan mal comprendido, no sólo en vida, sino aun mucho después»?

En castellano, hablar de incomprensión es exagerar, pues la obra de F. Schlegel obra de Franco Barrio es el de emplazar el texto en el diálogo filosófico de donde surge y al cual impreca. Kierkegaard fren teal hegelianismo ofrece, por tanto, en un gesto claramente enciclopédico, excelente material de consulta para toda lectura que desee orientarse en las categorías emblemáticas de la obra y el pensamiento kierkegaardianos, así como el mapa de autores con los que la producción de Kierkegaard guarda cierta relación, bien por haber recibido su influencia, bien por haberlos influenciado.

Begonya Sàez T ajafuerce Søren Kierkegaard Forskningscenteret. K.U.

(1772-1829) ha permanecido sin traducir hasta nuestros días (las O bras Selectastraducidas por H. Juretschke son de 1983, y la novela Lucinda, por otro lado inhaIlable hoy, traducida por Berta R aposo, es de 1987). En excelente traducción de R aposo es posible leer hoy la primera obra importante de F. Schlegel: Sobre el estu dio de la poeśa griega, escrita en 1794 y publicada en 1797.

El objetivo de este libro de Schlegel es desbrozar el camino que permita escribir una historia completa de la poesía griega (incluyendo en ella tanto la elocuencia como la historiografia, así como, curiosamente, la historia de la poesía romana). El conocimiento de la poesía griega a que apunta Schlegel no es, sin embargo, únicamente de tipo erudito. $\mathrm{N}$ i siquiera lo es principalmente. Pues dicho conocimiento es «una condición esencial para el perfeccionamiento del gusto y del arte ale mán» (p. 52) y, en el fondo, europeo. Es por esto que el lector se sorprende cuando ve que la mayor parte del libro se 
ocupa de desentrañar las características de la poesía moderna, antes que la griega. Incluso en ese aspecto más bien estadístico es clara la intención de Schlegel: el estudio de la poesía griega es una condición fundamental para conducir a la moderna hacia su acabamiento.

$\mathrm{N}$ o debe confundirse esta finalidad con la que propugnaban autores alemanes anteriores como W inckelmann, p.e., para quien lo bello era asequible, para los modernos, en el marco de la imitación del arte griego antiguo, entendiéndose esto no en el sentido vulgar de imitar pura y simplemente las obras acabadas sino sus principios formativos. Para F. Schlegel el conocimiento acabado del arte antiguo también es extremadamente importante para la práctica y enjuiciamiento del moderno, pero no en el mismo sentido en que lo era para clasicistas como W inckelmann.

La poesía antigua ha logrado sus metas y es, en su historia, un sistema acabado. No así la poesía moderna, que no ha logrado lo que busca, y ni siquiera tiene claro qué busca. La poesía moderna tiene en la griega un modelo, no en sus relaciones particulares, en tales o cuales obras, sino en el hecho de que aquélla se ha cerrado como sistema. Si la poesía moderna conoce sus propias peculiaridades, sus diferencias entre la poesía griega, le será posible, acto seguido, tomarla como modelo en la búsqueda del acabamiento de aquellas peculiaridades que la caracterizan. Eso es lo que Schelegel se propone en Sobreel estu dio de la poesía griega. Y es por eso que gran parte del libro está dedicado a describir diferencias entre lo antiguo y lo moderno. Sin esa descripción, el sentido en que lo griego puede ser modelo de lo moderno se pierde por completo, o se tergiversa en detrimiento de lo moderno, como ocurría en autores como W inckelmann. U na vez establecidas esas diferencias, debe intentarse un conocimiento acabado de la poesía antigua.

Los antiguos griegos vivieron en la belle za, y su arte alcanzó la belleza. D esde el comienzo hasta el fin el arte griego se movió en lo objetivo. Entre los modernos, por el contrario, lo bello aún está disperso, por así decir, pues en su arte rige lo quellama Schlegel lo subjetivo, «o interesante»: "todo individuo original que tenga una cantidad más o menos grande de contenido intel ectual o de energía esté tica» es interesante (p. 81). Pero lo interesante no es la meta del arte, ni siquiera del arte moderno, sino únicamente la pre paración y adelanto de aquello «objetivo» que para los griegos eran tan natural: «EI exceso de lo individual conduce, pues, por sí mismo a lo objetivo; lo interesante es la preparación de lo bello, y el fin último de la literatura moderna no puede ser otro que el summum bello, un máximo de perfección estética objetiva» (p. 81). La objetividad del arte griego se logró, según Schlegel, de un modo natural, salvaje, libre. C uando esa objetividad griega se disgrega, se pierde como tal, y el arte moderno, ya no natural sino artificial, nacerá disperso en lo interesante, en lo subjetivo.

Ahora bien, lo interesante es, para Schlegel, por muchos motivos, un síntoma de muerte cercana del arte moderno. $Y$ esto puede querer decir dos cosas: o que el arte moderno está siempre a punto de morir. 0 que está siempre a punto de dar el salto hacia adelante, hacia una dimensión en la que ya la muerte no sea posible, salto después del cual haya sólo la perspectiva de un avanzar infinito: un progreso. «Si [... ] el contenido filosófico predomina en la tendencia del gusto, y la natural eza es lo suficientemente fuerte como para no sucumbir ni a las más violentas sacudidas, entonces la fuerza centrípeta, después de haberse agotado en la producción de una excesiva plenitud de lo interesante, se recuperará y pasará a intentar lo objetivo. D e ahí que el auténtico gusto de nuestra época no sea ni un regalo de la naturaleza [griegos] ni un fruto sólo de la cultura [los modernos 
hasta ahora], sino únicamente posible bajo la condición de una mayor fuerza ética y una más firme independencia» (p. 82). Esta condición sólo se puede lograr, según Schlegel, mediante un salto repentino. Lo revolucionario, que está ocurriendo en Francia por los años en que Schlegel escribe este texto, hace su aparición en este punto: Io único que hará salir a la literatura moderna de la indecisión entre la muerte o la vida será un sal to revolucionario que la arranque del dominio de lo interesante subjetivo y la ponga de un golpe en un dominio objetivo en el que no sea posible más que el proceso legal hacia el logro de sus fines. La crítica de arte, que de este modo no sólo es normativa sino tambien cognoscitiva, tiene como primer fin mostrar a la poesía moderna y a sí misma cómo es una poesía cuando se mueve en ese plano objetivo: la poesía griega. Pues en el fondo, la poesía moderna europea no tienesino un origen común en aquella gran poesía. Y son esos dos vínculos que la conforman como tal poesía moderna europea: hacia atrás, su origen común en los griegos; su futuro común hacia una poesía moderna posible, hacia adelante. La crítica se mueve pendularmente entre aquel pasado y este futuro: indicando en ambas direcciones.

En qué grado se hayan cumplido los vaticinios, los deseos, o los temores expresados por Schlegel en este texto, es cuestión que está por formular.

D aniel Attala Pochón

\section{DROIT, R.-P.}

Le culte du N éant. Les philosophes et le Bouddha

París, Seuil, 1997, 367 p.

D urant el segle XIx la cultura filosòfica francesa, d'igual manera com succeí amb la nostra, fou receptora de les influències que li arribaven dels països més propers, però també d'algunes de més llunyanes, com és el cas del budisme. Fins ara sabíem poc del vincle que unia les dues tradicions filosòfiques i és per això que l'obra de Roger-Paul D roit es benvinguda per ajudar-nos a sortir d'aquest desconeixement. Per fer-nos una idea dela magnitud del'oblit cal fer una ullada a la bibliografia de més de cent pàgines que acompanya l'escrit. Es tracta d'un projecte d'investigació gestat des de fa temps. Abansn'havien apa regut dos Ilibres preparatoris: L'O ubli de l'Inde i Prèsences de Schopenhauer; a més de Philosophie, France, XIXème siè cle, fet en col·laboració amb Sthépan D ouailler i Patrice Vermeren, tots tres compromesos en un procés de revitalització del pensament francès del segle XIX, tantes vegades, d'una manera superficial, menystingut.
Ens trobem, sense cap gènere de dubtes, davant d'un treball sòlid, que mal grat el seu caràcter erudit es llegeix amb interès, i en el qual l'autor va desvetllant des del mateix text les claus de la seva investigació, reproduint les etapes que ell mateix va viure, amb les incerteses i els dubtes que en qual sevol treball com aquest sovint es presenten.

El budisme no és cap culteal no-res, afirma taxatiu l'autor al començament del IIibre, i el seu treball serà de demostrar a tra vés de les seves pàgines l'error que aquesta afirmació suposa. Això que avui en dia és tan evident no sembla que ho fos en el segle passat, ans al contarri, el budisme fou considerat com un perill que calia combatre amb totes les eines disponibles. Així ho feren, tant a Alemanya com a França, alguns dels més importants filòsofs de l'è poca. Els perills que cregueren trobar en el budisme foren de diferent ordre: religiós, metafísic, social i polític. D estaca entre els que el combateren, Victor C ou- 
sin, que fou qui afirmà, el 1863, que el budisme era un culte al no-res. El principal motiu de preocupació del factòtum de la institucionalització en el país veí era d'ordre polític. El moviment posava en qüestió l'ordre existent i, per tant, la seva perillositat era molt superior quesi d'una religió negativa s'hagués tractat.

És d'agrair, per tant, I'aparició de llibres com aquest que obren nous camins a la recerca fil osòfica i que són el fruit d'un llarg i pacient treball d'investigació i que, a la vegada, ens permeten afirmar que, gràcies al budisme i a d'altres moviments emancipatoris, ens trobem Iluny de considerar com a perilloses moltes de les pors que en segle xıx ho eren de la gent de bé.

Jordi Riba

\section{Colli, Giorgio}

Filosofía de la expresión

Traducción de M iguel M orey. Siruela. M adrid, 1996, 279 p.

\section{Invitación a la fiesta del conocimiento}

D ecía $\mathrm{N}$ ovalis que «el don del discernimiento, el juicio puro, cortante, sólo con suma prudencia puede aplicarse a los hombres, si no quiere herir de muerte y suscitar un odio general». A lo largo de toda su vida, Giorgio Colli (1917-1979) fue consciente de este hecho y supo que, si bien el amor a la verdad debe ser bello y sin reservas, el camino de vuelta, el querer decir la verdad, no es ya tan bello y puede sumir a quien lo emprende en el descrédito más generalizado o en la aclamación más ridícula.

$M$ irando de frente a los ojos de una larga tradición de pensamiento, dibujada con trazo preciso y silencioso, transcurre toda la obra de este pensador italiano: junto con M azzino M ontinari la edición crítica de las obras completas de N ietzsche; traducciones y ediciones críticas de obras de Platón, Aristóteles, Kant, Schopenhauer; la gran empresa editorial de la Enciclopedia de Autores C lásicos; diversos estudios sobre $\mathrm{N}$ ietzche y sobre el nacimiento de la filosofía; el proyecto de edición de los textos de la sabiduría arcaica, truncada por una muerte prematura; charlas radiofónicas; cursos universitarios, etc. En 1969 aparece Filosofia dell 'espressione, la obra que es objeto de nuestra reseña y que ha sido ahora editada en nuestro país. El libro se presenta con una excelente traducción de M iguel M orey que, cuando menos, conserva esa permanente reforma esotérica de la exposición filosófica a la que se encuentra «necesariamente» abocada la escritura colliana. Sin duda, nos hallamos ante una obra singular dentro del panorama del pensamiento filosófico contemporáneo. Su existencia casi inadvertida no nos aporta nada significativo sobre su val or. La historia es nuestra cómplice, pues, como todos sabemos, las alas de mariposa y los pasos de pal oma poseen efectos asombrosos y terribles.

La lucha contra la soberbia de la ciencia, contra la pretensión sistemática y optimista de la razón conduce a Colli, una vez aclarado el camino por la genealogía de la moral, a la indagación sobre la génesis teorética del logos. Sólo dicha génesis nos conduce realmente frente a las que Colli denomina «preguntas importantes»: ¿cómo se ha desarrollado la razón hasta la degeneración actual?, ¿en qué consiste, por contra, un uso sano de la razón?, ¿qué supone esta razón auténtica? El enigma, la dialéctica agonística y la retórica son las claves gracias a las cual es se vislumbra esta génesis teorética. Y Filosofía de la expre - 
són constituye la teoría general de ese logos renovado en sus orígenes. La obra, estructurada sutilmente entre la poesía de poderosas metáforas y la rigurosidad de unas deducciones trazadas casi more geometri co, se articula en tres partes: la primera, un análisis metafísico de la realidad simbolizado por el espejo de D ioniso, espejo que refleja el juego de violencia que hace aflorar en «la superficie las imágenes clarificadas de la apariencia, regidas por el dominio alternativo de lo necesario y lo casual» (p. 82). La segunda, un análisis lógico-gnoseológico del entramado cognoscitivo en el que se pone de manifiesto, en concordancia con el plano metafísico, la preeminencia de la modalidad (necesidad-contingencia), frente a la categoría de la cualidad, de donde se deduce una contradicción triangular en el seno de la propia razón. Esto conduce a la formulación y demostración de la «ley gene ral de la deducción»: «un objeto, si es, por necesidad no es; si no es, por necesidad es» (p. 180). D icha ley es requerida por la estructura de la apariencia, poniendo de manifiesto la modalidad que habita en el objeto necesario. La tercera, una historia de la razón, historia de la razón, mar- cada por dos mentiras sucesivas: la toma de autonomía de la expresividad impropia de la palabra escrita, que da lugar a un «ogos» espurio (p. 194 y s.); y la subordinación del conocimiento al punto de vista exclusivo del individuo, que supone la instrumentalización de la razón en función de la acción (p. 256 y s.). Todo ello ubicado en el espacio pertinente que le otorga su valor.

Aceptar la invitación que se nos hace en esta obra no es tarea fácil. En ningún momento ha escatimado el autor cualquier tipo de esfuerzo por nuestra parte. La posesión de lo realmente preciado nunca se nos ofrece de modo abierto, sino que sólo se adquiere dejando en el camino todo el empeño y la valía del pretendiente.

La obra concluye con un aparente regalo del que nada se nos había advertido en el índice: «una serie de preguntas sin orden aparente, con respuestas convenientemente ambiguas». T odo queda dicho en ellas sin que nada se diga. U na vez más la verdad se revela, pero sólo para el que se atreve a descifrarla.

M iguel Ángel López M uñoz

\section{GuZZonı, Ute}

U ber N atur. Aufzei chnungen unterwegs: zu einem anderen Naturverhältnis

Verlag Karl Alber, Freiburg/M unic, 1995

Wendungen. Versuche zu einem nicht identifizierenden D enken

Verlag Karl Alber, Freiburg/M unic, 1982

Amb l'experiència d'una dedicació de dècades a l'estudi de la tradició filosòfica, que els seus llibres, així com bona part de les seves classes a l'Albert-LudwigsU niversität de Freiburg, ens mostren concentrada especialment en Aristòtil, $\mathrm{H}$ egel i els dos extrems del pensament alemany contemporani, Adorno i H eidegger, l'autora torna un altre cop sobre aquells autors, però ara en un assai g amb preten- sions diferents de la literatura secundària, de la literatura sobre una al tra literatura. La intenció d'U ber $N$ atur s'expressa ja en la forma, que sorprèn tan bon punt es fulleja a la llibreria. L'índex, que ordena conceptes filosòfics de la manera més tradicional a les pàgines introductòries, desa pareix de la superfície en començar la lectura, ocult per l'ordre d'un diari personal, el diari d'un viatge. I els capítols que duen 
el nom de la ciutat on han estat escrits, en un recorregut per la M editerrània, Àsia i Amèrica, reivindiquen la importància d'abastar, del llibre estant, el lloc des d'on s'escriu, de parlar del món que acull l'autora, dels diferents paisatges que l'autora vista. La intenció és subratllada amb les fotografies que ens ofereixen la vista de què gaudia quan va escriure al guns dels capítols, l'última cosa que es pot esperar d'un llibre de filosofia, i que, lluny de respondre a un gust per l'ornamentació, insisteix en la voluntat de mirar enfora. La forma il.lustra així I'objectiu del treball: alliberar-se d'un cert pessimisme, del qual la lectura d'Adorno és en bona part cul pable, i mirar de pensar una nova relació amb la natura, on, per sobre dels nostres somiejos d'una harmonia estival que guarexi el dolor, cal que predomini la sensibilitat per la diferència i el fet de deixarse sorprendre per la natura tot cercant relacions de joc i descobriment.

En el Ilibre queda palès l'esforç de trobar I'estil més adient per oferir aquestes idees a un públic ben ampli. La claredat és un dels mèrits d'aquest treball, i si en algun moment el text queda pres en discussions especialment abstruses, no triga a deixar pas a una plaent descripció, de paisatges 0 de teories.

Així s'embarca Guzzoni durant més de 300 planes, en l'anàlisi de diverses mirades a la natura, fetes des de la llunyania o el fet de voler-se a prop, la confiança amb els riscos de la ingenuitat o la malfiança amb moments de lucidesa, l'erudició que ateny el mésínfim detall o el desconeixement que desemboca en la por. Les reflexions avancen amb l'agilitat que només permet un pòsit de cultura sedimentat durant anys de lectures, i vessat finalment en la comprensió de la nostra relació amb la natura, vessat, així doncs, a l'exterior. Fent del seu viatge no només forma, sinó també contingut, ens recull, així mateix, observacions sorprenents sobre la concepció de la natura en altres cultures; i fent tot seguit un viatge en el temps, res segueix a G rècia el naixement de la concepció de la «segona natura», per aplicarlo després a la nostra realitat, tan determinada ara per tots els objectes que introduïm en el món, i la vida pròpia de què semblen disposar quan sovint s'escapen al nostre control.

Un altre dels temes centrals és la relació entre la natura exterior i la que duem a dins nostre, però aquest és potser un dels llocs on es fa palès l'únic motiu de crítica que em desperta aquesta obra: que l'esforç permanent de vèncer el pessimisme li faci defugir d'enfrontar els llocs més foscos, on la relació amb la natura és contradictòria i dolorosa: el patiment, la violència, la injustícia. Guzzoni s'hi apropa al final en analitzar breument la D ialèctica de la II.lustració, però sense ganes de capbussar-s'hi. Q ui ja coneix què hi ha sota l'aigua té per un cop ganes, com somiejava Adorno als M inina M oralia, de surar en el balanceig de les ones dolçament al sol.

La lectura d'U ber $N$ atur és una bona introducció a aquesta autora, especialment quan, mirant enrere, decidim treballar un text més abstracte i difícil com és Wendun gen, I'altre II ibre que queda al marge de les seves monografies sobre diversos autors, però, aquest cop, no per pretendre mirar a l'exterior, sinó per intentar - a partir de l'anàlisi de sis temes diferents en textos on la brevetat té una relació proporcionalment inversa a la densitat- de tornar a definir alguns del s conceptes principals de la filosofia contemporània en cerca de noves possibilitats, de noves vies.

Un quadre de Cézane, I'ús en la tradició filosòfica de les metàfores de la foscor i la llum, o l'experiència del temps en les relacions personals, són punts de partida ben concrets per a una análisi de conceptes dirigida sempre a la recerca de les diferències, a recórrer tots els matisos defugint les superfícies planes i monocolors de la igual tat i la identitat. U na recerca de la convivència en un joc continu, actiu i 
aportador sempre de nous coneixements, entre contraris que no s' han de vèncer en una unitat que els elimina. I en destacaria especialment l'expressió d'aquestes idees amb l'anàlisi de les diferents formes del temps en les relacions humanes: des del moment potser casual de la primera trobada, fins a la memòria comuna, les expectatives compartides, o el temps de les converses i les discussions. C ada una d'aquestes vivències és analitzada des de la perspectiva de la finitud del temps, del final necessari de tota història compartida amb un al tre, fins que el text desemboca en la descripció de l'experiència de la separació o la pèrdua com el moment de màxima comprensió del que volen dir la diferència i la relació amb altri. Inspirada en $\mathrm{H}$ eidegger, el to allunya, pero, aquesta reflexió del pensament heideggerià, per tal com insisteix en la importància de les experiències de l'individu concret i la seva història, i acaba révindicant la continuació de l'esforç d'Adorno per posar els conceptes de finitud i diferència al servei d'una defensa de l'individu.

M arta T afalla

\section{DUCH, LI.}

La educación y la crisis dela modernidad Paidós, Colección Paidós Educador, Barcelona, 1997, 144 p.

Ens trobem davant una obra important. Pels que ens dediquem a la filosofia de l'educació serà sens dubtei a partir d'ara un punt de referència obligat. El seu autor, Lluís D uch, un dels antropòlegs més importants en aquest país, és sobradament conegut en l'àmbit de la seva especial itat, la fenomenologia de la religió o, més exactament, l'antropología de la religió. Ara, I'autor es proposa com a objectiu aplicar les tesis bàsiques del seu mètode antropològic al'anàlisi del fenomen educatiu i, més concretament, a l'estudi de les crisis de les transmissions en la societat moderna. Lluís D uch ja havia argumentat en altres llibres seus que la crisi del món modern era fonamentalment una crisi pedagògica. $\mathrm{Q}$ uè significa això? $\mathrm{V}$ ol dir que la crisi afecta fonamentalment les institucions encarregades de transmetrel'univers simbòlic a partir del qual l'ésser humà haurà de fer front al món.

L'ésser humà apareix caracterizat en l'obra de Lluís $D$ uch com un ens fràgil ambigu, indefinit, amb necessitat d'acolliment. També aquí l'autor recull plantejaments anteriors, però fent un èmfasi especial en la qüestió de les estructures d'acollida. Però, què és una estructura d'acollida? Lluís D uch afirma que les estructures d'a collida constitueixen el marc a l'interior del qual l'ésser humà pot posar en pràctica aquelles teodicees pràctiques que tenen la virtud d'instaurar, enmig de la provisional itat i novetat de la vida quotidiana, diverses pràctiques de dominació de la contingència. Si les institucionsi les estructures d'acollida entren en crisi no es pot fer front al «drama de la contingència». La relació, doncs, entre l'ésser humà (M ensch), I'educació i la contingència és la clau hermenèutica del IIibre que ens ocupa. L'ésser humà és con tingent perquè viu en situacions que no pot controlar i sobre les quals no pot expressar res de definitiu. La vida, el sofriment, la mort... tenen a veure amb allò que hi ha d'indisponible en l'existència humana, són expressions de la contingència. Ara bé, com es pot entendre el fenomen educatiu des d'aquest punt de vista? En la resposta a aquesta pregunta rau l'originalitat - al meu entendre- del llibre de Duch. 
L'educació és la transmissió d'un món simbòlic que fa possible la dominació de la contingencia. D it en altres paraules, l'educació és una teodicea pràctica. Sovint I'existència humana ens duu a atzucacs, però ningú pot superar aquest camí que no té sortida. Cal buscar i trobar el sentit. U na teodicea pràctica consisteix a cercar aquella paraula que faci possible encarar-se amb la contingència. Però, com i on es pot trobar la Paraula si aquesta es troba en l'Exili? O n queda la Paraula després de I'H olocaust? On es pot cercar la Paraula en la M odernitat?

Gran part de la crisi de l'home contemporani rau en la crisi de la tradició i de la memòria. Però per no es pot confondre la defensa de la importància de la tradició amb una apologia del passat i del retorn al passat. $\mathrm{N}$ omés hi ha tradició autèntica si hi ha re-creació en el present. Una tradició centrada en el passat és una tradició pervertida o àdhuc perversa. Però per tal de viure i d'actualitzar la tradició resulta fonamental la narració. L'ésser humà és un animal narratiu, capaç d'explicar històries, contes, mites. L'ésser humà és un l'animal que té Logos, però no en el sentit de R aó sinó en el de Paraula.

La Paraula humana, tanmateix, no és única. Lluís $D$ uch insisteix en què som éssers políglotes i polifònics. La polifonia és inherent a la condició humana. Aquesta afirmació té, ara més que mai, profundes conseqüències en filosofia i antropologia de l'educació. La pedagogia contemporània viu en un monolingüisme, i tot monolingüisme és, ens agradi o no, una forma de totalitarisme. N omés si ens exercitem en el poliglotisme podrem evitar les inevitables i fatals correspondències entre els discursos monològics (monocèntrics) i les praxis monolítiques.

La segona part del Ilibre comença estudiant la qüestió de l'ésser humà com a aprenent. Apendre a expressar i expressar-se no sha de reduir mai, segons D uch, a una mena de competència tècnica que ens permeti triomfar professionalment en la vida. El triomf personal pot ésser important, però no pas suficient. A prendre un llenguatge implica una lluita per tal que la paraula polifacètica retorni del seu exili. Cal evitar, sigui com sigui, la unidimensionalitat. En aquest sentit, el llibre de Lluís D uch és una esplèndida mostra de la tasca pedagògica fonamental: la lluita contra qual sevol forma de totalitarisme, entenent per totalitarisme la reducció de I'Altre al M ateix, de la D iferència a la I dentitat. U na pedagogia humana - l'única possible - ha de partir del polifacetisme de la Paraula. Una educació que només contempli una dimensió del llenguatge, sigui el concepte, sigui el símbol, és molt més a prop de l'adoctrinament que de l'educació. En tot reduccionisme hi ha una malaltia. L'educació des de la modernitat és en crisi, ara només cal esperar - com assenyala $\mathrm{D}$ uch amb paraules de $\mathrm{M}$ ax $\mathrm{H}$ orkheimer- que finalment ni el mal ni la mort tinguin la darrera paraula.

Joan-Carles M èlich U AB D epartament de Pedagogia Sistemàtica i Social 